\title{
The effect of invasive species Lantana Camara $L$. on soil nutrients at Ol-Donyo Sabuk National Park, Kenya
}

\author{
Wekhanya M. N. ${ }^{*}$, Mbugua P. K. ${ }^{1}$, Mworia J. K. ${ }^{2}$ \\ ${ }^{1 *}$ Department of Plant Sciences, Kenyatta University, Nairobi, Kenya, P.O Box 109-00902, Kikuyu-Kenya \\ ${ }^{1}$ Department of Plant Sciences, Kenyatta University, P. O. Box 43844-00100, Nairobi, Kenya \\ ${ }^{2}$ Department of Biological Sciences, Meru University of Science and Technology, \\ P.O Box ,972-60200, Meru-Kenya \\ ${ }^{1 *}$ Corresponding Author. Email: nangoniswek@gmail.com
}

Received: 18 July 2020 / Accepted: 29 September 2020 / Published online: 20 November 2020

\begin{abstract}
The aim of this study was to establish whether the invasive plant Lantana camara L. alters the soil chemical properties at Ol-Donyo Sabuk National Park. The key objective was to evaluate the soil nutrient composition in areas invaded by $L$. camara and how these differ from areas without L. camara. Five study sites were selected by purposeful sampling, out of the existing 10 blocks. Soil samples were collected randomly from $L$. camara invaded areas and similarly from adjacent areas free from L. camara. The soil samples were subjected to determination of the following nutrients and parameters: $\mathrm{pH}$, potassium $(\mathrm{K})$, calcium $(\mathrm{Ca})$ magnesium $(\mathrm{Mg})$, total nitrogen $(\mathrm{N})$, phosphorus (P), total organic carbon (TOC), manganese $(\mathrm{Mn})$, copper $(\mathrm{Cu})$, iron $(\mathrm{Fe})$, zinc $(\mathrm{Zn})$ and sodium $(\mathrm{Na})$. The data obtained was analysed using Two-way ANOVA test to determine difference in nutrients composition in L. camara invaded and non-invaded areas. Three-way ANOVA test was used to gauge the interactions between wet and dry season, invaded and non-invaded areas and study sites. A post-ANOVA test, Tukey's Honest Significant Difference was done to separate the means. The results from the study indicated L. camara invaded areas had a significant difference in $\mathrm{pH}, \mathrm{P}, \mathrm{N}, \mathrm{Mn}, \mathrm{Fe}$ and total organic $\mathrm{C}$ compared to the patches that had native plants and not invaded by L. camara. High $\mathrm{pH}$ also makes $\mathrm{P}$ to be more available to plants that is why $\mathrm{P}$ was high in the L. camara invaded areas. This study revealed that L. camara remarkably changes the concentration and balance of soil nutrients resulting to a change in chemistry of soil nutrients. This is in a bid to suit its survival to the
\end{abstract}

detriment of the native plant species. This study is hence vital for designing an effective eradication and preventive strategy of L. camara in Ol-Donyo Sabuk National Park and other protected ecological habitats in Kenya.

Keywords: Invasive species, native species, soil nutrients, ecosystems, Lantana camara L.

\section{INTRODUCTION}

Invasive species are a major ecological and management concern in natural ecosystems worldwide and pose a threat to many protected areas. Documentation on the invasion of $L$. camara in some countries is well done and in most of those countries Lantana was introduced for various reasons: ornamental, mulching of farms, to form hedges or medicinal (Ghisalberti, 2000). Day et al. (2003) show that in Uganda, Rwanda and Tanzania, invasion of habitats by $L$. camara affects crop production for coconuts and pineapples. L. camara also harbours tsetse flies. According to Le Maitre et al. (2000) L. camara had invaded a total area of 2 million hectares in South Africa, with a combined condensed area of almost 70,000 hectares. L. camara has also been connected to reduced diversity in invertebrates and reduced grazing grounds for herbivores by $80 \%$ (Van Wilgen et al., 2008).

Invasion can lead to the phasing out of native species and loss of ecosystem services such as water filtration, soil stabilization and pest control. Invasion may also result in reduction of wildlife forage or death of animals when they 
feed on poisonous invasive plant species. Invasion of native plant habitats by alien invasive species can drastically change soil chemical properties such as $\mathrm{pH}$, mineral composition, and mineral levels. L. camara is an insidious weed thought to have been introduced in East Africa in the 1930s (Verdcourt \& Polhill, 1992). It has since naturalized itself in many of the region's semi-arid areas including nature reserves where its negative effects cannot be under-estimated. Invasion of $L$. camara on native plant communities can cause changes in soil properties and species composition. Different levels of $L$. camara cover affect soil properties and herbaceous species composition (Sharma \& Raghubanshi, 2011). Results from the same study of Sharma and Raghubanshi (2011), indicate that as the Lantana cover increases some of the local species get extinct while some are indeed favoured by its invasion. Sharma and Raghubanshi (2011) also showed that the invasive $L$. camara affected soil nutrient levels such that concentration of organic $\mathrm{C}$ and total $\mathrm{N}$ were significantly higher in places that were heavily invaded. According to Rawat et al. (1994), its superiority in nitrogen extraction from the soil, along with an efficient re-translocation of $\mathrm{N}$ from the senescing leaves, enables $L$. camara to perform well as an invasive species. Several studies have shown that soil nutrient levels play an important role in determining community invasibility (Ehrenfeld, 2003; Hawkes et al., 2005; Reinhart and Callaway, 2006). This self-perpetuation changed microhabitat level probably providing $L$. camara with increased resources leading to its successful proliferation.

Some studies have shown that $L$. camara has allelopathic properties that inhibit seed germination and seedling growth of several native herbaceous and woody plants (An et al., 1998; Lwando, 2009). Allelopathy is a form of chemical competition or interference competition, whereby a plant secretes chemicals that make the surrounding soil un-inhabitable, or at least inhibitory, to competing species (Elisante \& Ndakidemi, 2014). Allelopathic chemicals potentially alter the basic nature of substrates in which plants grow and usually increase the competitive ability of the invasive species for certain nutrients uptake. Soil bacteria and fungi found in areas invaded by $L$. camara have been found to change nutrient cycling, leading to competitive outcomes in their favour and against natives (Hawkes et al., 2005). According to Simba et al. (2013), macro-nutrient concentrations of $\mathrm{Mg}, \mathrm{Ca}$ and $\mathrm{K}$ were higher in L. camara invaded sites than non-invaded sites, while $\mathrm{P}$ and $\mathrm{N}$ generally indicated low concentrations in the invaded sites relative to non-invaded sites. Again, high $\mathrm{pH}$ levels were recorded in soils invaded by $L$. camara. High soil $\mathrm{pH}$ is known to accelerate litter decomposition, and thus plays a crucial role in regulating nutrient availability. The concentration of macro-nutrients such as $\mathrm{Mg}$, $\mathrm{Ca}$ and $\mathrm{K}$ increased in $L$. camara invaded soils and this makes the plant leaves to be unpalatable to herbivores when crushed due to its unpleasant smell (Lui, 2011). This makes the plant not to be fed on by the herbivores, causing its upsurge in the invaded areas.

L. camara has invaded various conservation areas in Kenya, more specifically Ol-Donyo Sabuk National Park which has led to reduction of native vegetation in the Park. In addition, this invasive species has been found to drastically reduce above ground biomass by smothering native species, thus negatively affecting the abundance of wildlife forage and consequent loss of biodiversity (Wambua, 2010; Brocque et al., 2013). Ol-Donyo Sabuk National Park has a natural montane landscape with a rich biodiversity that requires protection from the invasive species for posterity. Despite a wealth of knowledge and many studies on the effects of invasive species, few studies have been done on their impacts on soil properties. This study therefore sought to understand the role played by this invasive plant species: L. camara in altering soil chemistry in its bid to effectively colonise the invaded areas at Ol-Donyo Sabuk National Park, Kenya.

Ol-Donyo Sabuk National Park is an isolated habitat patch which is surrounded by non- conservation land-uses resulting from privatisation of formerly large communal land. It is therefore prone to invasion by alien plants which are common in nearby agricultural farmlands. The Park has flora and fauna species that are threatened by the proliferation of invasive plant species (Obiri, 2011). In order to design an effective eradication and preventive strategy for the invasive species in such an important ecological habitat, the relationship between soil chemistry and plant invasion needs to be well understood.

\section{METHODOLOGY}

\section{Study Site}

The study location was Ol-Donyo Sabuk National Park (Figure 1), $85 \mathrm{~km}$ North-East of Nairobi in Machakos County $\left(10^{\circ} 5^{\prime}\right.$ to $10^{\circ} 10^{\prime} \mathrm{S} ; 37^{\circ} 10^{\prime}$ to $\left.37^{\circ} 20^{\prime} \mathrm{E}\right)$ and at an altitude of 2145 metres above sea level at the peak of the hill. The Park was gazetted by the Kenya Wildlife Service (KWS) in December 1967 and covers an area of 2068 hectares (KWS, 1999). Ol Donyo Sabuk, means large mountain in Maasai language. The Kikuyu community call it Kilimambogo 'the Mountain of the Buffalo' while the local people call the mountain by Kea-Njahe, meaning the 'Mountain of the Big Rain', one of Ngai's (God) lesser homes. The vegetation of the Park is mountane forest. Rainfall is bimodal between 800 to $2600 \mathrm{~mm}$ per annum (KMD, 2010), with rains occurring mostly from March to May (long rains) and October to December (short rains) 
with peaks in April and November. The maximum annual mean temperature is between $25^{\circ} \mathrm{C}-30^{\circ} \mathrm{C}$ and minimum annual mean is $18^{\circ} \mathrm{C}-20^{\circ} \mathrm{C}$. January-March is hot and dry; April-June is hot and wet; July to October is very warm and dry; November to December is warm and wet (KWS, 1999).

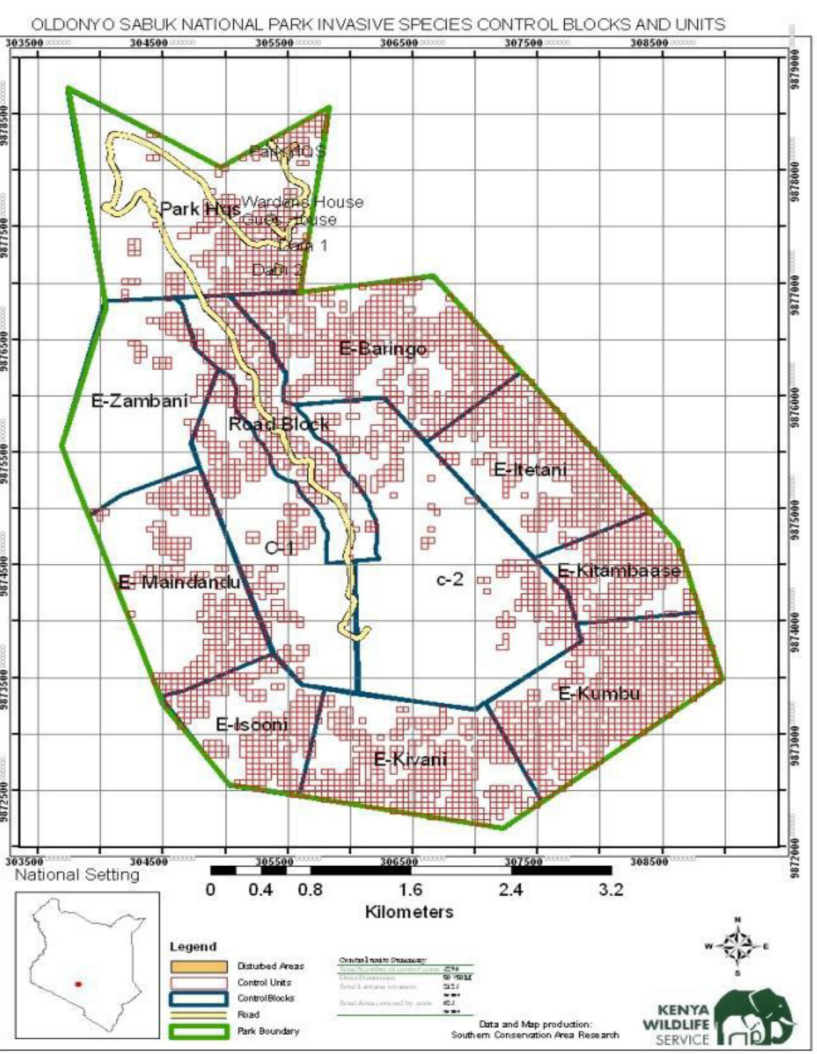

Figure 1. Map of Ol-Donyo Sabuk National Park Control Blocks for L. camara (KWS, 1999)

\section{Soil Sampling Design and Data Analysis}

The study was undertaken in the months of January and March 2014 for the dry season sampling, while the wet season sampling was carried out between November and December 2014. The Park covers an area of 2068 hectares (KWS, 1999) and has been divided into 10 control blocks each measuring approximately 200 hectares. By purposeful sampling, 5 blocks were selected: Baringo, Park Head quarter, Isooni, Zambani, and Kitambasie, out of the 10 blocks for study. These blocks that were selected based on security from wild animals, represented varying altitudes of the study area and accessibility.

In each block, 2 quadrants $(10 \mathrm{mx} 10 \mathrm{~m})$ at intervals of $>100 \mathrm{~m}$ were established randomly, using a tape measure and wooden pegs. One quadrant was invaded by L. camara and the other had native plant species (non-invaded). Each quadrant was further sub-divided into 2 strata due to steep terrain (upper and lower). In each stratum of the quadrant 20 sampling points were randomly established. Soil samples were then collected using a soil auger to a depth of 30 centimetres. The soil samples were collected directly under the canopies of $L$. camara and that of native species. This was done to get the direct effects of the plant. The soil samples were analysed at the Kenya Agricultural and Livestock Research Organization (KALRO) Kabete laboratories in three replicates, and averages obtained. The following nutrients and parameters were determined and analysed using Two-way and Three-way ANOVA tests: soil $\mathrm{pH}, \mathrm{K}, \mathrm{Ca}, \mathrm{Mg}$, total N, P, TOC, Mn, Cu, Fe, Zn and $\mathrm{Na}$.

\section{RESULTS}

During the wet and dry season, $\mathrm{pH}$ value varied significantly ( $\mathrm{P}$-value $<0.0001)$. The $\mathrm{pH}$ value was higher during the dry season, compared to the wet season (6.59 and 6.39 respectively). There was a significant difference (P-value $<0.0001$ ) between the L. camara invaded and non-invaded areas. The Lantana invaded areas had higher $\mathrm{pH}$ value (6.59) compared to the non-invaded areas that had $\mathrm{pH}$ value (6.30). There was significant interaction (P-value $<0.0001)$ between wet and dry season and Lantana invaded areas in influencing $\mathrm{pH}$ in the soil (Table $1)$.

Total $\mathrm{N}$ concentration varied significantly $(\mathrm{P}$-value $=0.0111$ ) during both seasons. Total $\mathrm{N}$ concentration was higher during the dry season (mean $0.27 \%$ ) than the wet season (mean 0.17\%). There was significant difference (P-value 0.0271 ) between the L. camara invaded and non-invaded areas. The $L$. camara invaded areas had higher (mean $0.26 \%$ ) in total $\mathrm{N}$ concentration compared to the noninvaded areas (mean 0.18\%). Concentration of total $\mathrm{N}$ varied significantly $(\mathrm{P}$-value $=0.0111)$ between wet and dry season and L. camara invaded and non-invaded areas. There was significant interaction $(\mathrm{P}$-value $=0.0111)$ between the wet and dry season and L. camara invaded areas in influencing total $\mathrm{N}$ concentration in the soil (Table 1).

TOC concentration varied significantly (P-value $<0.0001$ ) during both wet and dry season. TOC concentration was higher during the dry season (mean 1.85\%) compared to the wet season that had lower mean (1.61\%). There was no significant difference $(\mathrm{P}$-value $=0.8377$ ) between the $L$. camara invaded and non-invaded areas. There was significant interaction (P-value $<0.0001$ ) between wet and dry season and $L$. camara invaded areas in influencing total organic $\mathrm{C}$ concentration in the soil (Table 1 ).

$\mathrm{P}$ concentration varied significantly $(\mathrm{P}$-value $=0.0004)$ during both wet and dry season. The P concentration was higher during the wet season compared to the dry season (mean of $19.78 \mathrm{mEq} \%$ and $20.00 \mathrm{mEq} \%$ respectively). P concentration varied significantly (P-value $<0.0001$ ) in the $L$. camara invaded and non-invaded areas. There was 
significant interaction $(\mathrm{P}$-value $=0.0004)$ between wet and dry season and $L$. camara invaded areas in influencing $P$ concentration in the soil (Table 1).

During the wet and dry season $\mathrm{K}$ concentration varied significantly (P-value $<0.0001)$. The concentration of $\mathrm{K}$ was higher during the wet season compared to the dry season (mean of $2.18 \mathrm{mEq} \%$ and $1.49 \mathrm{mEq} \%$ respectively). There was significant difference $(\mathrm{P}$-value $=0.0037)$ between the $L$. camara invaded and non-invaded areas. The areas not invaded by $L$. camara had higher mean $(1.89 \mathrm{mEq} \%)$ in $\mathrm{K}$ concentration compared to the non-invaded areas that had lower mean $(1.79 \mathrm{mEq} \%)$. The concentration of $\mathrm{K}$ varied significantly (P-value $<0.0001)$ between the wet and dry season and $L$. camara invaded areas in influencing $\mathrm{K}$ concentration in the soil (Table 1).

The concentration of $\mathrm{Ca}$ did not vary significantly $(\mathrm{P}$-value $=0.2054)$ during both wet and dry season and between the $L$. camara invaded and non- invaded areas. $\mathrm{Mg}$ concentration varied significantly (P-value $<0.0001$ ) during both wet and dry season. The concentration of $\mathrm{Mg}$ was higher during the wet season (mean $3.02 \mathrm{mEq} \%$ ) compared to the dry season (mean $2.73 \mathrm{mEq} \%$ ). There was significant difference ( $\mathrm{P}$-value $<0.0001$ ) between the $L$. camara invaded and non-invaded areas. The $L$. camara non-invaded areas had higher mean of $(3.04 \mathrm{mEq} \%)$ in
$\mathrm{Mg}$ concentration compared to the invaded areas that had a lower mean $(2.71 \mathrm{mEq} \%)$. There was significant interaction (P-value $<0.0001$ ) between invaded and noninvaded areas and the wet and dry season in influencing $\mathrm{Mg}$ concentration in the soil (Table 1).

Mn concentration varied significantly (P-value $<0.0001)$ during both wet and dry season. The concentration of $\mathrm{Mn}$ was higher during the dry season with a mean of $0.96 \mathrm{mEq} \%$, compared to the wet season mean of $0.86 \mathrm{mEq} \%$. There was significant difference (P-value $<0.0001$ ) between the L. camara invaded and non-invaded areas. The L. camara invaded areas had higher mean $(0.99 \mathrm{mEq} \%)$ in $\mathrm{Mn}$ concentration compared to the noninvaded areas mean $(0.83 \mathrm{mEq} \%)$. There was significant interaction (P-value $<0.0001$ ) between wet and dry season and $L$. camara invaded areas in influencing manganese concentration in the soil. There was significant interaction $(P$-value $=0.0508)$ among the study sites and $L$. camara invaded areas in influencing manganese concentration in the soil (Table 1).

Concentration of $\mathrm{Cu}$ varied significantly (P-value $<0.0001$ ) during both wet and dry season. The concentration of $\mathrm{Cu}$ was higher during the dry season (mean 10.13ppm) compared to the wet season (mean 9.42ppm). There was significant difference $(\mathrm{P}$-value $<0.0001)$ between the $L$.

Table 1. Three-way ANOVA showing interactions between $\mathrm{PH}$, nutrients and seasons

\begin{tabular}{|c|c|c|c|c|c|c|c|c|c|c|c|c|}
\hline $\begin{array}{l}\text { Treatmen } \\
t\end{array}$ & Soil pH & $\begin{array}{l}\text { Total N } \\
\%\end{array}$ & $\begin{array}{l}\text { Organic C } \\
\%\end{array}$ & $\begin{array}{c}\mathrm{P} \\
\mathrm{mEq} \%\end{array}$ & $\begin{array}{l}\mathrm{K} \\
\mathrm{mEq} \%\end{array}$ & $\begin{array}{l}\mathrm{Ca} \\
\mathrm{mEq} \%\end{array}$ & $\begin{array}{c}\mathrm{Mg} \\
\mathrm{mEq} \%\end{array}$ & $\begin{array}{l}\text { Mn } \\
\text { mEq\% }\end{array}$ & $\begin{array}{l}\mathrm{Cu} \\
\text { ppm }\end{array}$ & $\begin{array}{l}\mathrm{Fe} \\
\mathrm{ppm}\end{array}$ & $\begin{array}{l}\mathrm{Zn} \\
\text { Ppm }\end{array}$ & $\begin{array}{l}\mathrm{Na} \\
\mathrm{mEq} \%\end{array}$ \\
\hline \multicolumn{13}{|l|}{ Season } \\
\hline Dry & $6.59 \pm 0.13^{\mathrm{a}}$ & $0.27 \pm 0.05^{\mathrm{a}}$ & $1.85 \pm 0.06^{\mathrm{a}}$ & $19.78 \pm 2.05^{\mathrm{a}}$ & $1.49 \pm 0.24^{\mathrm{a}}$ & $6.26 \pm 0.60^{\mathrm{aa}}$ & $2.73 \pm 0.14^{\mathrm{a}}$ & $0.96 \pm 0.07^{\mathrm{a}}$ & $10.13 \pm 0.35^{\mathrm{a}}$ & $21.19 \pm 1.46^{\mathrm{a}}$ & $6.41 \pm 0.76^{\mathrm{a}}$ & $0.61 \pm 0.11^{\mathrm{a}}$ \\
\hline Wet & $6.39 \pm 0.09^{b}$ & $0.17 \pm 0.01^{\mathrm{b}}$ & $1.61 \pm 0.08^{\mathrm{b}}$ & $20.00 \pm 1.70^{\mathrm{b}}$ & $2.19 \pm 0.33^{b}$ & $16.15 \pm 8.34^{\mathrm{a}}$ & $3.02 \pm 0.18^{\mathrm{b}}$ & $0.86 \pm 0.08^{b}$ & $9.42 \pm 0.5 \mathrm{l}^{\mathrm{b}}$ & $16.70 \pm 0.77^{\mathrm{b}}$ & $9.77 \pm 1.32^{b}$ & $0.67 \pm 0.11^{b}$ \\
\hline $\begin{array}{l}\text { Site } \\
\text { Baringo }\end{array}$ & $6.95 \pm 0.12^{\mathrm{a}}$ & $0.20 \pm 0.00^{\mathrm{ab}}$ & $2.00 \pm 0.05^{\mathrm{aa}}$ & $20.77 \pm 2.84^{\mathrm{b}}$ & $1.23 \pm 0.05^{\mathrm{cc}}$ & $5.21 \pm 0.10^{\mathrm{bb}}$ & $2.56 \pm 0.02^{\mathrm{b}}$ & $0.98 \pm 0.03^{\mathrm{c}}$ & $10.25 \pm 0.36^{\mathrm{b}}$ & $14.60 \pm 0.54^{\mathrm{e}}$ & $14.98 \pm 2.31^{\mathrm{a}}$ & $0.37 \pm 0.00^{\mathrm{d}}$ \\
\hline Kitambasi & $6.36 \pm 0.08^{c}$ & $0.31 \pm 0.12^{\mathrm{a}}$ & $1.29 \pm 0.08^{c}$ & $17.53 \pm 3.07^{\mathrm{d}}$ & $4.07 \pm 0.66^{\mathrm{a}}$ & $33.66 \pm 20.32^{\mathrm{a}}$ & $4.34 \pm 0.33^{\mathrm{a}}$ & $0.45 \pm 0.09^{\mathrm{e}}$ & $7.85 \pm 0.32^{\mathrm{d}}$ & $24.18 \pm 2.07^{\mathrm{a}}$ & $2.46 \pm 0.17^{\mathrm{e}}$ & $1.53 \pm 0.26^{\mathrm{a}}$ \\
\hline Nzambani & $6.48 \pm 0.20^{\mathrm{b}}$ & $0.19 \pm 0.01^{\mathrm{b}}$ & $1.90 \pm 0.06^{\mathrm{a}}$ & $12.28 \pm 2.35^{\mathrm{e}}$ & $0.97 \pm 0.27^{d}$ & $4.37 \pm 0.80^{\mathrm{b}}$ & $2.50 \pm 0.04^{\mathrm{c}}$ & $0.73 \pm 0.13^{d}$ & $10.69 \pm 0.67^{\text {aa }}$ & $21.54 \pm 2.70^{\mathrm{b}}$ & $7.10 \pm 0.32^{\circ}$ & $0.34 \pm 0.07^{\mathrm{e}}$ \\
\hline Park HQ & $6.60 \pm 0.25^{\mathrm{bb}}$ & $0.17 \pm 0.01^{\mathrm{b}}$ & $1.67 \pm 0.08^{\mathrm{b}}$ & $20.00 \pm 3.19^{\mathrm{c}}$ & $1.12 \pm 0.21^{\mathrm{c}}$ & $5.90 \pm 0.34^{\mathrm{bb}}$ & $2.45 \pm 0.06^{\mathrm{d}}$ & $1.06 \pm 0.03^{\mathrm{b}}$ & $9.41 \pm 1.13^{\mathrm{c}}$ & $16.17 \pm 1.43^{\mathrm{d}}$ & $5.48 \pm 0.51^{\mathrm{d}}$ & $0.45 \pm 0.02^{\mathrm{c}}$ \\
\hline $\begin{array}{l}\text { Treatment } \\
\text { Invaded }\end{array}$ & $6.68 \pm 0.12^{\mathrm{a}}$ & $0.26 \pm 0.05^{\mathrm{a}}$ & $1.73 \pm 0.08^{\mathrm{aa}}$ & $20.93 \pm 2.21^{a}$ & $1.79 \pm 0.31^{\mathrm{a}}$ & $15.54 \pm 8.35^{\text {aа }}$ & $2.71 \pm 0.14^{\mathrm{a}}$ & $0.99 \pm 0.06^{\mathrm{a}}$ & $8.68 \pm 0.41^{\mathrm{a}}$ & $20.57 \pm 1.65^{\mathrm{a}}$ & $6.69 \pm 0.75^{\mathrm{a}}$ & $0.64 \pm 0.11^{\text {aa }}$ \\
\hline $\begin{array}{l}\text { Non- } \\
\text { invaded }\end{array}$ & $6.30 \pm 0.09^{b}$ & $0.18 \pm 0.01^{\mathrm{b}}$ & $1.72 \pm 0.07^{\mathrm{a}}$ & $20.93 \pm 2.21^{\mathrm{b}}$ & $1.89 \pm 0.29^{b}$ & $6.87 \pm 0.75^{\mathrm{a}}$ & $3.04 \pm 0.18^{\mathrm{b}}$ & $0.83 \pm 0.08^{\mathrm{b}}$ & $10.88 \pm 0.37^{b}$ & $17.32 \pm 0.42^{b}$ & $9.50 \pm 1.34^{\mathrm{b}}$ & $0.64 \pm 0.12^{\mathrm{a}}$ \\
\hline $\begin{array}{l}\text { P-values } \\
\text { Season }\end{array}$ & $<0.0001$ & 0.0111 & $<0.0001$ & 0.0004 & $<0.0001$ & 0.2054 & $<0.0001$ & $<0.0001$ & $<0.0001$ & $<0.0001$ & $<0.0001$ & $<0.0001$ \\
\hline Site & $<0.0001$ & 0.1476 & $<0.0001$ & $<0.0001$ & $<0.0001$ & 0.0927 & $<0.0001$ & $<0.0001$ & $<0.0001$ & $<0.0001$ & $<0.0001$ & $<0.0001$ \\
\hline Treatment & $<0.0001$ & 0.0271 & 0.8377 & $<0.0001$ & 0.0037 & 0.2659 & $<0.0001$ & $<0.0001$ & $<0.0001$ & $<0.0001$ & $<0.0001$ & 0.8931 \\
\hline Site*Sn & $<0.0001$ & 0.0228 & 0.0163 & $<0.0001$ & $<0.0001$ & 0.1774 & $<0.0001$ & $<0.0001$ & $<0.0001$ & $<0.0001$ & $<0.0001$ & $<0.0001$ \\
\hline Season ${ }^{\star} \mathrm{Tr}$ & $<0.0001$ & 0.0111 & $<0.0001$ & 0.0004 & $<0.0001$ & 0.2054 & $<0.0001$ & 0.0508 & $<0.0001$ & $<0.0001$ & $<0.0001$ & $<0.0001$ \\
\hline Site $^{\star x} \mathrm{Tr}$ & $<0.0001$ & 0.0401 & $<0.0001$ & $<0.0001$ & $<0.0001$ & 0.4411 & $<0.0001$ & $<0.0001$ & $<0.0001$ & $<0.0001$ & $<0.0001$ & $<0.0001$ \\
\hline Site ${ }^{*} \operatorname{Sn}{ }^{*} \operatorname{Tr}$ & $<0.0001$ & 0.0228 & 0.0163 & $<0.0001$ & $<0.0001$ & 0.1774 & $<0.0001$ & $<0.0001$ & $<0.0001$ & $<0.0001$ & $<0.0001$ & $<0.0001$ \\
\hline
\end{tabular}

+ Mean \pm SD value followed by the same letter(s) within the same column do not differ significantly from one another (Three-way ANOVA, Tukey HSD-test, $\alpha=0.05$ ), $\mathbf{p p m}$ stands for Parts per million, $\mathbf{S n}$ stands for season, mEq stands for milli equivalents while $\mathbf{T r}$ stands for treatment. 
camara invaded and non-invaded areas. The concentration of copper was higher in the L. camara non-invaded areas than the invaded (mean of $10.88 \mathrm{ppm}$ and $6.68 \mathrm{ppm}$ respectively). There was significant interaction (P-value $<0.0001$ ) between wet and dry season and $L$. camara invaded areas in influencing copper concentration in the soil (Table 1).

During the wet and dry seasons, the concentration of Fe varied significantly (P-value $<0.0001$ ). The concentration of Fe was higher during the dry season (mean 21.19ppm) compared to the wet season (mean $16.70 \mathrm{ppm}$ ). There was significant difference (P-value $<0.0001)$ between the $L$. camara invaded and non-invaded areas. Fe concentration was higher in the $L$. camara invaded areas compared to the non-invaded areas (mean of 20.57ppm and 17.32ppm respectively). There was significant interaction (P-value $<0.0001$ ) between wet and dry season and $L$. camara invaded areas in influencing iron concentration in the soil (Table 1).

Zn concentration varied significantly (P-value $<0.0001$ ) during both wet and dry season. The concentration of $\mathrm{Zn}$ was higher during the wet season (mean $(9.77 \mathrm{ppm})$ compared to the dry season (mean $(6.41 \mathrm{ppm})$. There was significant difference (P-value $<0.0001)$ between the $L$. camara invaded and non-invaded areas. The $L$. camara non-invaded areas had higher mean (9.50ppm) in $\mathrm{Zn}$ concentration compared to the invaded areas mean (6.69ppm). There was significant interaction (P-value $<0.0001)$ between wet and dry season and $L$. camara invaded areas in influencing $\mathrm{Zn}$ concentration in the soil (Table 1).

$\mathrm{Na}$ concentration varied significantly $(\mathrm{P}$-value $<0.0001)$ during both wet and dry season. The concentration of $\mathrm{Na}$ was higher during the wet season (mean $0.67 \mathrm{ppm}$ ) compared to the dry season (mean $(0.61 \mathrm{ppm})$. There was no significant difference $(\mathrm{P}$-value $=0.8931)$ between the $L$. camara invaded and non-invaded areas. Both $L$. camara invaded and non-invaded areas had the same concentration of $\mathrm{Na}$ with a mean of $0.64 \mathrm{ppm}$. There was significant interaction ( $\mathrm{P}$-value $<0.0001$ ) between wet and dry season and L. camara invaded areas in influencing $\mathrm{Na}$ concentration in the soil (Table 1).

There was a difference in the amount of $\mathrm{pH}$ and nutrients in the areas invaded by L. camara and the none invaded except for $\mathrm{P}$ that had same concentration in both sites $(20.93 \mathrm{mEq} \%)$ (Table 2). This is also illustrated in the graphs (Figure $2 \& 3$ ).

Table 2. Two-way ANOVA showing summary of soil properties in Lantana camara invaded and non-invaded patches across five sites in Oldonyo Sabuk Park

\begin{tabular}{|c|c|c|c|c|c|}
\hline \multirow[t]{2}{*}{ Soil Nutrient } & \multicolumn{3}{|c|}{ Summary ANOVA } & \multicolumn{2}{|c|}{ Group Mean $( \pm$ SE $)$} \\
\hline & Site $(\mathrm{S})$ & Invasion (I) & S x I Interaction & $\begin{array}{l}\text { Non-Invaded } \\
(\mathrm{N}=5 \text { sites })\end{array}$ & Invaded $(\mathrm{N}=5$ sites $)$ \\
\hline Soil $^{\mathrm{pH}}$ & $* * * *$ & $* * * *$ & $* * * *$ & $6.30 \pm 0.09 \mathrm{~b}$ & $6.68 \pm 0.12 \mathrm{a}$ \\
\hline Total N \% & NS & $*$ & * & $0.18 \pm 0.0 \mathrm{~b}$ & $0.26 \pm 0.05 \mathrm{a}$ \\
\hline Organic C \% & $* * * *$ & NS & $* * * *$ & $1.72 \pm 0.07 \mathrm{a}$ & $1.73 \pm 0.08 \mathrm{aa}$ \\
\hline P mEq \% & $* * * *$ & $* * * *$ & $* * * *$ & $20.93 \pm 2.21 b$ & $20.93 \pm 2.21 \mathrm{a}$ \\
\hline K mEq \% & $* * * *$ & $* *$ & $* * * *$ & $1.89 \pm 0.29 \mathrm{~b}$ & $1.79 \pm 0.31 \mathrm{a}$ \\
\hline Ca mEq \% & NS & NS & NS & $6.87 \pm 0.75 \mathrm{a}$ & $15.54 \pm 8.35 \mathrm{aa}$ \\
\hline Mg mEq \% & $* * * *$ & $* * * *$ & $* * * *$ & $3.04 \pm 0.18 b$ & $2.71 \pm 0.14 \mathrm{a}$ \\
\hline Mn mEq \% & $* * * *$ & $* * * *$ & $* * * *$ & $0.83 \pm 0.08 \mathrm{~b}$ & $0.99 \pm 0.06 \mathrm{a}$ \\
\hline Cu ppm & $* * * *$ & $* * * *$ & $* * * *$ & $10.88 \pm 0.37 \mathrm{~b}$ & $8.68 \pm 0.41 \mathrm{a}$ \\
\hline Fe ppm & $* * * *$ & $* * * *$ & $* * * *$ & $17.32 \pm 0.42 \mathrm{~b}$ & $20.57 \pm 1.65 \mathrm{a}$ \\
\hline Zn ppm & $* * * *$ & $* * * *$ & $* * * *$ & $9.50 \pm 1.34 \mathrm{~b}$ & $6.69 \pm 0.75 \mathrm{a}$ \\
\hline Na mEq \% & $* * * *$ & NS & $* * * *$ & $0.64 \pm 0.12 \mathrm{a}$ & $0.64 \pm 0.11 \mathrm{aa}$ \\
\hline
\end{tabular}

ppm stands for Parts per million, $\mathbf{m E q}$ stands for milli equivalents 


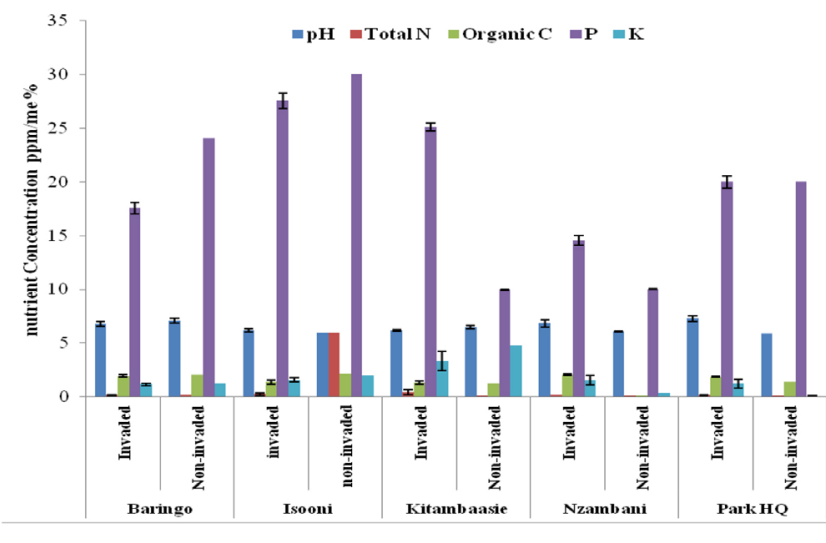

Figure 2. Comparison of $\mathrm{PH}$ and nutrient levels in the invaded areas by L. camara and none invaded areas in 5 study sites

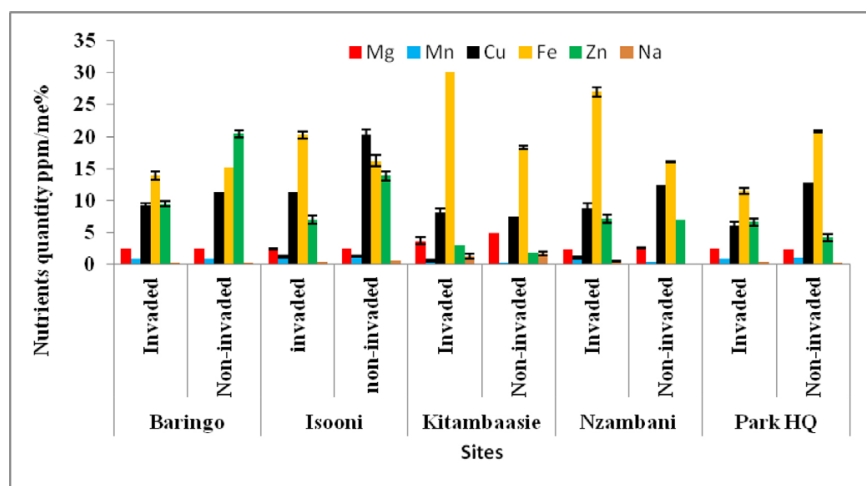

Figure 3. Comparison of nutrient levels in the invaded areas by L. camara and none invaded areas in 5 study sites

\section{DISCUSSION}

There was significant difference ( $\mathrm{P}$-value $<0.05$ ) in zinc, iron, copper magnesium and manganese across all the study sites between the L. camara invaded and noninvaded areas. $\mathrm{Na}$ showed no significant difference in the invaded and non-invaded areas. $\mathrm{Mn}$ and $\mathrm{Fe}$ were in high concentrations in L. camara invaded areas while $\mathrm{Mg}, \mathrm{Cu}$ and $\mathrm{Zn}$ were in high concentrations in the noninvaded areas. The concentration of $\mathrm{Na}$ was the same in both invaded and non-invaded areas. These results are contrary to Osunkonya and Perret (2010) who reported that there was lower soil $\mathrm{Cu}, \mathrm{Fe}$ and $\mathrm{Mn}$ recorded within L. camara infestations than from non-infested soils; salt concentrations in the form of total chlorine, and exchangeable $\mathrm{Na}$ were also lower within L. camara patches. In the current study the concentration of $\mathrm{Mn}$ and Fe were found to be higher in concentration in L. camara invaded areas which agrees with Osunkonya and Perret (2010). According to Liptzin and Silver (2009) high levels of Fe are known to decrease microbial activity and availability of free nutrients for plant root uptake generating oxidative stress hence negatively affecting plant growth. This could be a characteristic adapted by the invasive plant $L$. camara to increase the concentration of $\mathrm{Fe}$ as obtained in the results so that it can colonise the habitats of native plants eliminating them. According to Li et al. (2013), soil macro-nutrients form a large proportion of soil quality indicators, and therefore their measurements are essential in biodiversity conservation, hence their soil concentrations were measured in this study. There is no documented data on the soil $\mathrm{pH}$ and nutrient composition of Ol-Donyo Sabuk National Park before the Park was invaded by $L$. camara to be used for comparison with the current study.

The L. camara invaded areas in study sites had leaf litter under the canopies slightly more than $2.5 \mathrm{~cm}$; this is probably because, as reported by Simba et al. (2013) L camara being a highly branched species with a lot of leaf biomass released its leaf tissues with time and accumulated a lot of litter within its understory, approximately more than $2.5 \mathrm{~cm}$, where there is $100 \%$ invasion and where there is $30-50 \%$ invasion the litter is less than $2.5 \mathrm{~cm}$. There was a higher concentration total $\mathrm{N}$ in L. camara invaded areas in the study sites and this can be attributed to L. camara leaf litter. The concentration of litter $\mathrm{N}$ of invasive plants is often higher than that of native plants (Liao et al., 2008). The findings of this study are also in agreement with Mandal and Guantum (2014), who reported that increase in $\mathrm{N}$ and $\mathrm{P}$ levels with increase in L. camara intensity could be due to decrease in nutrient impounding, followed by the displacement of native species or reduction in their recruitment and growth rates. In this study there were higher concentrations of $\mathrm{N}$ and $\mathrm{P}$ in L. camara invaded areas. According to Sharma and Raghubanshi (2009), L. camara architecture promotes accumulation of litter under the shrub resulting to build up of organic $\mathrm{C}$ and $\mathrm{N}$ and this is similar to this study where $\mathrm{C}$ and $\mathrm{N}$ levels were elevated in the L. camara invaded areas.

According to Osunkonya and Perret (2010), under the L. camara patch only the availability of soil $\mathrm{Ca}, \mathrm{P}$ and $\mathrm{C}$ correlated significantly and positively with increasing $\mathrm{pH}(\mathrm{r}=0.62,0.71,0.68$, respectively; $\mathrm{P}<0.05, \mathrm{~N}=22)$, while $\mathrm{Na}$ and $\mathrm{Fe}$ showed the opposite pattern $(\mathrm{r}=-0.97$, -0.64 , respectively; $\mathrm{P}<0.05, \mathrm{~N}=22$ ). These trends can be expected because under elevated $\mathrm{pH}$, the soil exchange complex is no longer dominated by hydrogen ions $(\mathrm{H}+)$, a process that might make mineral ions more accessible for plant function and growth. Soil $\mathrm{pH}$ has a major role in controlling nutrient bioavailability (Weidenhamer \& Callaway, 2010). The litter of L. camara has low lignin and high $\mathrm{N}$ combined with a good micro-climate below the canopy of $L$. camara it increases the rate of litter decomposition. These changes in litter input result in increasing the $\mathrm{N}$ in the soil and other nutrients which also result in faster growth of the plant in comparison to other 
plant species in the vicinity (Sharma et al., 2005). Across all the five study sites, the results showed a change in the concentration of soil nutrients and $\mathrm{pH}$ in the L. camara invaded areas which makes the environment favourable for its invasion in Ol-Donyo Sabuk National Park.

\section{CONCLUSION}

From the results presented, it is clear that $L$. camara modulates soil properties for the better in areas under its invasion favouring its dominance and perhaps affecting the population of other plant species. This phenomenon is already visible in Ol-Donyo Sabuk National Park. This change of soil chemical properties to its favour enables the plant $L$. camara to outperform other native species and in the process enhancing its invasiveness. Together with the impacts of climate change and the need to improve on the resilience of the Park such proliferation of invasive species like L. camara is better avoided or reduced. As a way forward, such studies should be encouraged to enable better understand the relationships between invasive plant species and soil nutrients more or so to promote sciencebased management of the Parks for effective conservation of biodiversity. Also, it might help if further research is undertaken to determine whether other plant species are also affecting the soil properties in the Park other than $L$. camara.

\section{REFERENCES}

An, M., Pratley, J. E., \& Haig, T. (1998). Allelopathy: from concept to reality. Report on $9^{\text {th }}$ Australian agronomy conference. Charles Sturt University, Wagga Wagga, NSW 2650.

Brocque, A., Case, H., \& Dearnaley, J. (2013). Response of soil fungal richness and composition to Lantana camara L. Infestation in the Toowoomba Region, South-East Queensland, Australia. Australasian Mycologist, 31, 17-23.

Day, M. D., Wiley, C. J., Playford, J., \& Zalucki, M. P. (2003). Lantana: current management status and future prospects. Australian Centre for International Agricultural Research, Canberra, Australia.

Ehrenfeld, J. (2003). Effects of exotic plant invasions on soil nutrient cycling processes. Ecosystems, 6, 503-523.

Elisante, F., \& Ndakidemi, P. (2014). Allelopathic effect of Datura stramonium on the survival of grass and legume species in the conservation areas. American Journal of Research Communication, 2(1), 27-43.

Ghisalberti, E. L. (2000). Lantana camara L. (Verbenaceae). Fitoterapia, 71(5), 467-486.

Hashim A.B., Aminuddin H., \& Siva K.B. (1996). Nutrient content of rice husk ash of some Malaysian rice varieties. Journal of Tropical Agriculture Science, 19(1),77-80.
Hawkes, C., Wren, I., Herman, D., \& Firestone, M. (2005). Plant invasion alters nitrogen cycling by modifying the soil nitrifying community. Ecology Letters, 8, 976-985.

Kenya Meteorological Department-KMD (2010). Climatological statistics for Kenya. Nairobi, Kenya.

Kenya Wildlife Service-KWS. (1999). Fourteen falls/ oldonyo sabuk integrated management plan. Nairobi, Kenya.

Le Maitre, D. C., Versfeld, D. B., \& Chapman, R. A. (2000). Impact of invading alien plants on surface water resources in South Africa: A preliminary assessment. Technical note. Water South Africa, 26(3), 397-408.

Li, P., Zhang, T., \& Wang, Y. D. (2013). Development of biological soil quality indicator system for sub-tropical China. Soil and Tillage Research, 126, 112-118.

Liao, C., Peng, R., Luo, Y., Zhou, X., Wu, X., \& Fang, C. (2008). Altered ecosystem carbon and nitrogen cycles by plant invasion. New Phytologist, 177, 706-714.

Liptzin, D., \& Silver, W. (2009). Effects of carbon additions on iron reduction and phosphorus availability in humid tropical forest soils. Soil Biology and Biochemistry, 41, 1696-1702.

Lüi, X. (2011). Quantitative risk analysis and prediction of potential distribution areas of common Lantana camara in China. Computational Ecology and Software, 1(1), 60-65.

Lwando, C. (2009). Effect of Lantana camara on plant diversity in Zambia. WWF- Education for Nature Program, 1-4.

Mandal, G., \& Joshi, S. P. (2014). The role of soil nutrient availability on the invasion establishment and carbon sequestration potential of an invasive shrub from doon valley, India. Journal of Advanced Botany and Zoology, 14(8), 1-12.

Obiri, J. F. (2011). Invasive plant species and their disastereffects in dry tropical forests and rangelands of Kenya and Tanzania. Journal of Disaster Risk Studies, 3(2), 417-428.

Osunkoya, O., \& Perret, C. (2010). Lantana camara L. (Verbenaceae). Invasion effects on soil physio-chemical properties. Biological Fertility Soils, 47, 349-355.

Rawat, Y., Bhatt, Y., Pande, P. \& Singh, S. (1994). Production and nutrient cycling in Arundinaria Falcata and Lantana camara. The two converted ecosystems in central Himalaya. Tropical Ecology, 35(1), 53-67.

Reinhart, K., \& Callaway, R. (2006). Soil Biota and Invasive Plants. New Phytology, 170, 445-457.

Sharma, G., \& Raghubanshi, A. (2011). Lantana Camara L. Invasion and Impact on Herb Layer Diversity and Soil Properties in a Dry Deciduous Forest of India. Applied Ecology and Environmental Research, 3, 253264.

Sharma, G. P., Raghubanshi, A. S., \& Singh, J. S. (2005). 
Lantana invasion: an overview. Weed Biology and Management, 5(4), 157-165.

Simba, Y. R., Kamweya, A. M., Mwangi, P. N., \& Ochora, J. M. (2013). Impact of the invasive shrub, Lantana camara L. on soil properties in Nairobi National Park, Kenya. International Journal of Biodiversity and Conservation, 5(12), 803-809.

Van Wilgen, B. W., Reyers, B., Le Maitre, D. C., Richardson, D. M., \& Schonegevel, L. (2008). A biome-scale assessment of the impact of invasive alien plants on ecosystem services in South Africa. Journal of Environmental Management, 89(4), 336-349.

Verdcourt, B., \& Polhill, R. M. (1992). Flora of tropical East Africa-Verbenaceae. First Edition. CRC Press.

Wambua, J. K. (2010). The distribution, abundance and ecological impacts of invasive plant species at Ol-Donyo Sabuk National Park, Kenya. Doctoral dissertation, University of Nairobi. Retrieved from http://erepository. uonbi.ac.ke:8080/xmlui/handle/123456789/12139

Weidenhamer, J., \& Callaway, R. (2010). Direct and indirect effects of invasive plants on soil chemistry and ecosystem function. Chemical Ecology, 36, 59-69. 